\title{
Vocational Education and Learners' Experienced Workplace Curriculum
}

\author{
Heta Rintala ${ }^{1}$ (D) Petri Nokelainen ${ }^{1}$
}

Received: 15 February 2019 / Accepted: 15 July 2019 / Published online: 8 August 2019

(C) The Author(s) 2019

\begin{abstract}
There has been a growing emphasis on providing students in vocational education and training (VET) with workplace experiences. School-based VET and apprenticeship training have been parallel routes in the Finnish VET system, but relatively little is known of their characteristics regarding students' experiences. This study addresses this research gap by investigating these two VET pathways and addressing the following research question: How do learners experience workplace learning on various learning pathways? This study further investigates three different vocational fields: social and health care, business and administration, and construction. The study was based on semi-structured individual interviews $(N=33)$ : 18 of the participants were students in school-based VET, and 15 were apprentices. The interview data were analysed with thematic analysis. The themes highlighted how the VET pathway builds a frame for participation that is then shaped by work practices and social practices and how, eventually, individuals alter boundaries to participation. The study implies that the two VET pathways, school-based VET and apprenticeship training, have significant differences. However, in the construction sector, differences between students' experiences of workplace learning seem to be less visible. Based on learning experiences, it seems that apprenticeship training and school-based VET cannot be considered parallel or interchangeable routes. This should be acknowledged because the recent reform of vocational upper secondary education aims to advance a flexible combination of school- and work-based pathways, and it can also be considered when discussing the coherence of VET systems.
\end{abstract}

Keywords Vocational education · Workplace learning · Curriculum · Student experiences

Heta Rintala

heta.rintala@tuni.fi

Petri Nokelainen

petri.nokelainen@tuni.fi

1 Faculty of Education and Culture, Tampere University, Åkerlundinkatu 5,

FI-33014 Tampere, Finland 


\section{Introduction}

In vocational education and training (VET), apprenticeships and other forms of work-based learning have been promoted at the policy level in recent years (European Council 2018). This development requires understanding of how work-based learning experiences, such as apprenticeships or school-based VET including on-the-job training periods, are provided and made into effective learning opportunities. These both modes of education, school-based VET and apprenticeship training, co-exist in Finland, but in comparison to countries that mainly organise VET through apprenticeship training, Finland has mainly promoted school-based VET. This has been due to various historical developments, including the centralisation of schooling in order to support equal educational opportunities (Stenström and Virolainen 2018).

However, in full-time school-based VET, there has also been a growing emphasis on providing students with workplace learning experiences since the $1990 \mathrm{~s}$ (Virolainen and Persson Thunqvist 2017). Until 2018, upper secondary schoolbased VET lasting 3 years usually included 6 months of instruction at the workplace (on-the-job learning). Next to school-based VET, apprenticeship training has complemented the VET system and provided an educational pathway mainly for adults (Mazenod 2016; Stenström and Virolainen 2018). Apprenticeship training has been tightly connected to regular employment because it is based on a fixedterm employment contract entitling the student to a salary based on an applicable collective agreement. Thus, apprentice pay has been rather high in comparison to other countries (cf. Ryan et al. 2013).

The reform of vocational upper secondary education, which came into force in 2018, aimed to further increase work-based learning, and thus, no minimum or maximum time was set for workplace learning in school-based VET. In the competence-based VET system, school-based VET and apprenticeships are officially parallel learning pathways as they follow the same national qualification requirements. Instead of final examinations to assure a common standard, competence is demonstrated and assessed in practical tasks during workplace learning. The reform of upper secondary VET has aimed to promote individual competence needs, and, thus, also instead of focusing on time served and a standardised approach, it has highlighted flexibility, including the flexible combining of school-based and work-based learning pathways (Finnish National Agency for Education 2018). These both pathways and qualifications provide eligibility for higher education. However, this article argues that the two learning pathways, school-based VET with on-the-job learning periods (currently via a training agreement) and apprenticeship training, cannot be considered as parallel or easily interchangeable based on learners' experiences of workplace learning.

In VET, as well as in the reform context, it should be noted that the kinds of workplace experiences that are provided to students, as well as their sequencing, duration and traditions, can have significant educational consequences. Identifying differences between VET pathways or vocational fields has been found to be challenging as the variance between individuals is often high (Poortman 2007). However, previous studies have suggested that diverse learning experiences are related to differences, for example, in competence and vocational identity development (Bound and Lin 2013; Grytnes et al. 2018; Virtanen et al. 2008, 2014a), creativity and 
productivity at work (i.e. developing new methods and completing tasks) (Fjellström and Kristmansson 2016) and commitment to the occupation and orga nisation (Bound and Lin 2013). This study aims to contribute to an understanding of the nature of workplace learning experiences and how these differ across VET pathways, vocational fields and workplace settings. This study addresses the following research question: How do learners experience workplace learning on various learning pathways?

\section{Theoretical Framework}

Vocational curricula generally include both school-based and work-based learning. Connectivity (Guile and Griffiths 2001) and integrating practices and different forms of knowledge are usually considered essential for the development of vocational competence (Mikkonen et al. 2017; Tynjälä 2013). Often, the quality of workplace learning has been considered an issue, and, thus, learning in the workplace can benefit from being supplemented by experiences in school-based education (Aarkrog 2005; Akkerman and Bakker 2012; Onstenk and Blokhuis 2007). However, the dichotomy between school and work emphasises their different goals, rationales, and types of knowledge (Aarkrog 2005; Schaap et al. 2012). It seems that individuals' conceptions of connectivity or alignment between education and work are highly variable; while some consider learning experiences as separate, others may consider them complementary (Sappa and Aprea 2014). The principle of gradual release (Evans et al. 2013, p. 158) suggests that the sequencing of the elements should allow iterative development and ensure that school and workplace curricula are not separate sites of learning where it is the learner's task to connect theory and practice.

As a frame, this study considers workplace learning in VET as more or less intentionally organised activity towards full and effective work performance, with this being referred to as a learning curriculum (Lave and Wenger 1991), a situated curriculum (Gherardi et al. 1998) or a workplace curriculum (Billett 2006, 2011). This view of workplace learning as pathways of activities is based on Lave and Wenger's (1991) legitimate peripheral participation, which includes that learning must be situated in authentic, real-life contexts where learners or newcomers are allowed to interact with experts, and, eventually, the learner may become a full participant. Thus, this study takes a position in a socio-cultural paradigm and emphasises the importance of context, culture and the social aspects of learning (Lave and Wenger 1991; Billett 2004). More specifically, this study is rooted in learners' experienced curriculum (Billett 2006), i.e. what learners eventually experience and interpret when they participate in workplace learning in VET. According to Thornton Moore (2004), this type of curriculum of experience is shaped by the external environment covering other institutions and wider society, features of the organisation including roles, production processes and culture, but also by personal features of the learners, including educational histories or dispositions that they have when entering the workplace.

In workplaces, the sequencing of activities often includes the logic of increasing economic impact (Gherardi et al. 1998), a movement from activities with low 
accountability levels, error costs and standing to tasks of higher accountability and standing (Billett 2006). However, Fjellström and Kristmansson (2016) compared construction worker and shop salesperson apprentices and found that apprentices in construction work often performed complex tasks with high accountability. In a similar manner, Reegård (2015) examined apprentices in the retail sector and noticed that they were given a great deal of autonomy and responsibility from early on. Although workplace learning is part of VET, it is not always intentionally structured, and educational goals may be overridden by workplace goals and activities (Fjellström and Kristmansson 2016). Goller et al. (2018) investigated novice aides' learning processes in nursing homes. They similarly noticed that a fast transition into productive work was expected to fully capitalise novice aides. Novice aides started with care-related activities and moved from simple cases to more demanding ones, minimising the consequences of errors and preventing discouragement and potential early dropout.

Progression can be promoted by support and guidance (Billett 2002, 2006; Mikkonen et al. 2017; Swager et al. 2015). Swager et al. (2015) underlined interaction and argued that guidance widely includes psychosocial support, structure-providing interventions (matching learners and trainers, as well as organising assessments) and didactical interventions to promote educational goals via goal-setting, selecting and sequencing tasks and providing support. Studies of workplace learning often emphasise the role of collaboration, interaction and shared practices, but students also tend to report that they learn alone (Virtanen et al. 2009). In practice, support and guidance are realised in varying ways. Reegård (2015) found that managers had no plan for organising training for retail apprentices, and this approach implied minimal instruction and guidance. However, granting responsibility to apprentices contributed to learning and selfconfidence when the given responsibility was mastered. This shows that workplace learning can be characterised as co-participation, as an interplay between what opportunities are given and how learners are able to engage with the opportunities (Billett 2004, 2006). Learners' own abilities, motivation, goals and experiences shape participation and active engagement, and, for instance, the ability to demonstrate competence in activities is likely needed for movement to more demanding tasks (Billett 2006; Tynjälä 2013). In the Finnish context, Virtanen et al. (2014a) found through a survey that student-related individual factors were not considered equally important in relation to workplace learning outcomes in all vocational fields: individual factors, including motivational orientations and prior work experience, were especially related to workplace learning in the field of technology and transport.

The choice of engaging is also related to agency that is often considered as an individual feature or something that individuals do (Goller and Harteis 2017). Often, agency is considered relevant or even a necessary condition for learning, for example, novice aides were expected to actively seek information, feedback and social interaction to get access to new learning opportunities (Goller et al. 2018). Here, the focus is on these kinds of learners' agentic actions that may include versatile "self-initiated and goal-directed behaviours that aim to take control over the work environment and/or the acting individual's life" (Goller and Harteis 2017, p. 88). Agency is also influenced by the context (Eteläpelto 
2017; Goller and Harteis 2017). For example, learners' engagement and agency can be influenced by providing them with a legitimate and influential role, allowing autonomy and independent work instead of a marginalised position, and by providing opportunities to observe others and to receive guidance (Bouw et al. 2019; Mikkonen et al. 2017). Regarding the VET system as a context, Grytnes et al. (2018) concluded that connectivity and learners' employment status during workplace learning varied in the construction sector in Danish and Swedish VET systems and, thus, affected safety practices adopted by learners. They found that Swedish students were novices for a longer time, had the right to voice concerns about safety and teachers acted as students' advocates, whereas Danish employed apprentices highlighted the role of the supervisors and considered safety standards as an expense and an ideal compared to practice.

\section{Method}

\section{Context and Participants}

The present study investigates and compares vocational students' experienced workplace curriculum on various VET pathways. This study focuses on three vocational fields: social and health care, construction, and business and administration. These fields were chosen to be studied further as previous quantitative studies in the Finnish VET and on-the-job learning context (Virtanen et al. 2008, $2014 \mathrm{a}, \mathrm{b})$ suggested that these fields have different workplace learning practices. These studies (Virtanen et al. 2008, 2014a, b) included wider vocational sectors, and it was found that, compared to the technology and transport sector (including construction), social services and the health care sector made more effort to integrate school and workplace learning, had more supportive and expansive learning environments and encouraged students' vocational identity development. The business and administration sector seemed to be located somewhere between the two above-mentioned fields (Virtanen et al. 2014b).

This study focuses on three vocational upper secondary qualifications: the vocational upper secondary qualification in social and health care, the vocational upper secondary qualification in construction and the vocational upper secondary qualification in business and administration. All of these qualifications include compulsory units and versatile specialisations or so called competence areas. The participants of this study included future practical nurses with versatile specialisations (apprentices focusing either on care for the elderly, children and youth care and education or mental health and substance abuse welfare work) or students yet to choose their specialisation, future builders and infrastructure builders and apprentices, and students focusing either on customer services and sales or financial and office services. The students in school-based VET were in their first year (business and administration) or second year of studies (social and health care, construction), and apprentices had mainly started their training in 2017 , the year of data collection.

As mentioned in the introduction, both school-based VET and apprenticeship training exist in Finland. Of these two modes of education or pathways, schoolbased VET is the primary route, with apprenticeship training having an $18.47 \%$ 
share of qualifications in 2017 (Education Statistics Finland 2018). Regarding initial preparation, Finland has mainly relied on the state-led, school-based model of VET, although the curriculum has included compulsory on-the-job learning periods (minimum of half a year for a three-year study period) in the $2000 \mathrm{~s}$ (Virolainen and Persson Thunqvist 2017). In 2017, of the new students in apprenticeship training, only $14.75 \%$ were $15-24$ year olds (Education Statistics Finland 2018). The sample (see Table 1) of this study consisted of 33 participants, of which 15 were apprentices and 18 were students in school-based VET. As Table 1 illustrates, the apprentices were older than the students in school-based VET, which is a noticeable characteristic of Finnish VET.

\section{Data Collection and Analysis}

Participants were informed about the study, and they voluntarily provided signed consent forms and permission to record the interviews. Their anonymity was ensured. The data were collected through semi-structured individual interviews, which were conducted at workplaces or at the vocational schools. The interviews included versatile themes and questions related to vocational expertise, workplace learning, education and work and future plans. This study focused on questions about learning experiences, for example: How would you describe your work community/communities? How would you describe your tasks? The apprentices' interviews lasted from 37 to 100 minutes, whereas the students' interviews were shorter, lasting from 37 to $63 \mathrm{~min}$. The interviews were transcribed verbatim. The software programme NVivo was used to manage the data and the coding process.

Thematic analysis (TA) was chosen as a method because it is not bounded by research paradigms or theoretical commitments, and it can be applied to studying people's experiences in that it aims to identify, analyse and report patterns, i.e. themes, within data (Braun and Clarke 2006; Clarke and Braun 2017; Terry et al. 2017). The analysis began with a familiarisation process, during which the data

Table 1 Overview of the research participants $(N=33)$

\begin{tabular}{|c|c|c|c|c|}
\hline \multirow[t]{2}{*}{ Mode of education } & \multirow[t]{2}{*}{ Participants } & \multicolumn{3}{|c|}{ Vocational field } \\
\hline & & $\begin{array}{l}\text { Social and } \\
\text { health care }\end{array}$ & $\begin{array}{l}\text { Business } \\
\text { and administration }\end{array}$ & Construction \\
\hline \multirow{4}{*}{$\begin{array}{l}\text { Apprenticeships } \\
\text { Fixed-term employment } \\
\text { relationship (min. } 25 \mathrm{~h} \text { per week), } \\
\text { usually two contact days per } \\
\text { month at vocational school }\end{array}$} & Apprentices $n$ & 7 & 4 & 4 \\
\hline & Male $n$ & 3 & 3 & 3 \\
\hline & Female $n$ & 4 & 1 & 1 \\
\hline & Age $M$ (range) & $38.8(22-49)$ & $24.5(16-33)$ & 20.5 (17-27) \\
\hline \multirow{5}{*}{$\begin{array}{l}\text { School-based VET } \\
\text { Full-time study including } \\
\text { on-the-job learning periods (often } \\
5 \text { weeks each, in total min. half a } \\
\text { year for a three-year study period) }\end{array}$} & Students $n$ & 6 & 6 & 6 \\
\hline & Male $n$ & 1 & 1 & 5 \\
\hline & Female $n$ & 5 & 5 & 1 \\
\hline & Age $M$ (range) & $17.5(17-18)$ & $16.8(16-17)$ & $17.7(17-18)$ \\
\hline & Students in total $N$ & 13 & 10 & 10 \\
\hline
\end{tabular}


were read multiple times. This phase was followed by coding, with codes being the smallest units of analysis that capture relevant features of the data in relation to the research question (Clarke and Braun 2017). The coding was initially inductive, and the codes focused on students' experiences of the chosen VET pathway and workplace experiences. To emphasise this, the codes were formed from the students" perspective (e.g. "Student status allows me to seek guidance", "The community does not trust me", and "The teacher is the best person to assess my learning and competence"). After coding the items, the codes were compiled into list of codes to identify patterns and diversity. In this TA approach, based on Braun and Clarke (2006, see also Terry et al. 2017), the aim is not only to organise and summarise patterns but also to interpret these patterns and attempt to theorise the significance of the patterns, often in relation to the literature. Thus, the codes were combined and collapsed into themes centred on an idea or concept. During this phase, theme development was considered in relation to the literature and the entire dataset. This eventually led to an abductive analysis arising from the participants' experiences, but theoretical background was also acknowledged. The approach taken in this study emphasises that these themes do not emerge from the data. Rather, they are created by the researcher. Thus, the needed quality assurance strategies include the strict reviewing of themes to ensure their compatibility with the entire dataset and the coded data (Terry et al. 2017). Ultimately, four themes were chosen to interpret the student's experiences of workplace learning as a part of VET. The first theme highlights the meaning of context and the chosen VET pathway, the second theme focuses on the needs of the work and how the work practices shape the individual's participation, the third theme shows the meaning of social practices and interactions and the fourth theme describes how learners decide to participate in experiences and elect to exercise their agency in workplaces.

\section{Findings}

\section{Theme 1: The VET Pathway Builds a Frame for Participation}

Most students in school-based VET expressed that school is a preparation for work because it aims to ensure readiness to enter the workplace by providing the basic vocational skills needed in work tasks and also by conveying general knowledge about working life, such as employees' rights and obligations. The students were prepared for each five-week period of workplace learning by focusing on certain timely themes prior to this training. Practical nurse students in the social and health care field appreciated the opportunity to practise skills in school, without pressure, because the mistakes did not lead to any serious consequences. Therefore, simulations and hands-on practice with mannequins in school were important parts of their preparation for work. They also felt that the compulsory units of the qualification supported their slow progress towards completing more difficult and specialised tasks; they started workplace learning with daycare duties, from which they next progressed to assisting with nursing tasks and eventually focused on more individualised and patient-centred methods of working, before choosing a 
specialisation. In the business sector, students similarly appreciated the opportunity to prepare for workplace learning by focusing on one thing at a time and practising the skills needed at work, such as social skills or language skills. The only compulsory unit for all apprentices focused on customer service, and these skills were further practised at work. Most often, on-the-job learning (usually 5 weeks) was considered as allowing participation in multiple communities and tasks, however, some individuals felt that the time was too short for understanding and mastering whole work processes and that the workplace learning opportunities did not match educational goals or the future profession.

In both the social and health care and business and administration fields, most of the students experienced that they were encouraged to set goals that could be achieved and discussed later in the assessment. In practice, this kind of goal setting and planning was realised at various levels, and two students critiqued planning for its focus on papers instead of discussions. However, planning was especially elaborated upon in the social and health care field, where only one student reported not to have planned workplace learning. Otherwise, students were encouraged and guided by their teachers:

Mainly, you just go and work there [workplace]. Then, of course, at school, they have told you that you have to come up with the goals, the tasks you have to do, and also with the competence demonstration plan. You have to do all the competence demonstration plans and give them to the supervising teacher and the workplace trainer. They accept them, and then, you proceed to the competence demonstration if they think that it is ok. (student_social)

In contrast, the apprentices emphasised the importance of workplace learning that was often tailored to match the needs of a workplace. Apprentices felt that the aim was to receive a qualification and employment. All apprentices acknowledged and accepted that their studies and learning were dependent on the learning opportunities in the workplace, which also limited their opportunities to plan their own studies. Instead of specialising at the end of their studies, the apprentices often started their studies by specialising in tasks required in a specific workplace. Hence, setting educational goals was more demanding and secondary. Often, the role of vocational school and education was experienced as unclear, distant or poorly aligned with workplace experiences. In addition, a few individuals experienced that apprenticeship training requires self-study, whereas some felt that it is mainly independent work that especially provides workspecific skills. However, in individual accounts, vocational school and contact teaching for a few days (often two) per month was found to enrich learning via providing theory, the correct working methods and opportunities for peer interaction. The following extracts show that a strong work-based focus of apprenticeship training was considered as an asset, but also as a challenge in relation to connectivity and employability:

I have got everything I need, work-wise, from the workplace. The vocational school provides, at least this far, only extra. Last time we had geometry, it is fun but something I don't need. (apprentice_construction) 
I think this is good, but I consider that there should be some contact days [at vocational school], otherwise it feels a bit like a negligence. I think that, for example, two days in a month, but when you have none. Someone asked me in the beginning what it has been like to study, but I don't feel like I am studying. Of course, now, when I had two exams back to back, and I had to retake the other one, I have been reading a lot and felt very much like a student. But I think that there should be some contact days, personally, I need those. (apprentice_social)

It [apprenticeship] prepares you very well for the work you are doing. The problem of the apprenticeship, if you want to consider it as a problem, is that it does not necessarily teach - many companies wish that this would be developed further. In practice, it provides work-specific knowledge, which is not good for the wider interests of the society. (apprentice_business)

\section{Theme 2: Work Practices Shape Participation}

Despite the differences in organising VET pathways, in the construction sector, both students in school-based VET and apprentices reported that tasks and their sequencing cannot be planned as they are based on workplaces' or customers' needs. Thus, education and work were considered to be poorly aligned and incompatible. Individuals told of how they preferred workplace learning and authentic work tasks, as the studies in vocational school were judged to offer theory and ideal ways of working that differed from the practices in the workplaces. Experiences were shaped by the work and the workplaces' goals as the learning path at work was outlined by workplaces and assignments, sometimes even on a day-to-day basis:

In the beginning, there were less demanding tasks, something that you could do, and there was no chance to cause any damage or anything, but every year it has been like the responsibility has grown. Now it is like that you have to go wherever you have to go. They are no longer thinking whether you can manage, as they did in the beginning. (student_construction)

Most of the interviewed apprentices and students in the field had similar experiences, they often described how they started with more peripheral tasks to avoid potentially expensive consequences. Based on participants' individual views, the progression to more independent tasks was difficult because they worked on assistive tasks (in small companies), on specialised tasks (in large companies) or they did not have access to tools or resources. A few students in the school-based VET had additional rights and limitations because they were minors, and safety rules restricted their participation in tasks involving imminent danger, such as roof work and concrete works on construction sites.

In contrast, practical nurse students in school-based VET reported that they had easy access to basic care activities. After observing others, access to more independent, still guided, tasks was granted in a few days, but only if the student was ready to take on this responsibility. The tasks could also be negotiated, and, for example, in one case participation in taking care of a dead 
person's body or dealing with the relatives after his or her death was not required as a part of nursing and care duties. However, all apprentices in social and health care felt that they were expected to participate in work as employees from the beginning. Only dispensing medication and inputting patient data into the repository were, in most cases, off limits for them. Four out of seven apprentices felt that the role of learner was sometimes forgotten and actual skills and competence contradicted expectations or that an introduction to the work was lacking. Eventually, this was overcome by individuals by focusing on routine tasks first and then learning new tasks as they presented themselves, as one apprentice experienced:

In the beginning, it was a bit strange and I wanted to complain that is there was no one who could guide or brief me, but then maybe, I have adapted myself to that quite easily and seen that all the situations are so different that there is no point to explain those in detail. (apprentice_social)

In business and administration, apprentices in the field worked under various job titles as assistants or in sales. As in the social and health care field, they were given tasks that were similar to those of other workers, although compared to others, they saw themselves as having less experience. Due to their previous work experience, they were mainly autonomous workers in their current jobs, and they experienced that they participated in challenging tasks, problem-solving and various networks. In this field, students in school-based VET also experienced that they participated in similar tasks compared to others, but as students, they had the right to ask for and receive guidance. In a couple of cases, workplaces even provided students with planned tasks and goals for each week and shift. Most often, students, during their first on-the-job learning periods, participated first in filling shelves and then moved on to customer service and the responsibility granted by the right to use a cash register. The following extract describes the role of a student during on-the-job learning:

I was mainly a trainee, I had responsibilities, but if I say that an employee had a 100 per cent responsibility so then I had like 80 to 85 per cent. So, basically, it was counted that if a mistake happens, it is not the end of the world, and there was not too much pressure. There was a good balance. A nice role so that it was not boring, but then again I did not have to work my fingers to the bone, because that is not good either. A nice one, so that the work kept you alert. (student_business)

\section{Theme 3: Social Interactions and Practices Shape Participation}

Most of the interviewees felt that they were accepted as a member of the community because they were trusted and given proper tasks and responsibilities based on discussions about their previous experiences. In rare cases, participants felt that they were not fully trusted in the community, for example, due to previous negative experiences, and the atmosphere in some workplaces led to feelings of discouragement or 
neglect because learners' views were dismissed, their participation was limited or they witnessed bad practices.

In most cases, co-workers supported participation and provided guidance and feedback on tasks. In business and administration, participants in this study described co-workers' role only in positive terms. However, in other fields, both negative and positive views on co-workers and their participation and guidance were voiced. In the social and health care field, co-workers were most often considered to understand and value previous knowledge and skills, and both students and apprentices had access to more independent tasks. However, in some cases working alongside more experienced workers or the trainer was considered as a challenge as it hindered the demonstration of competence and put learners into a more peripheral role. One student told how she could take care of patients in a relatively good shape independently, but when taking care of students in poor shape and working with a more experienced nurse, she was given more physically demanding or less meaningful tasks. In another case, the activity of the trainer was considered to allow the student to adopt an inactive role. Thus, distributing work equally was considered a challenge when working with others.

In the construction sector, both students and apprentices considered themselves as junior workers in the hierarchy. In this kind of hierarchy, feedback and acceptance from supervisors were especially important, but all students felt that co-workers were the best people to assess their competence and progress. However, their progression into more difficult tasks was impeded by work practices, but also by their co-workers and the culture of the workplaces. Positioned lower in the hierarchy, they were often left with assistive tasks, and sometimes their ideas were not acknowledged when working with more experienced workers:

I can do everything in my own way, in my own order, when I am alone. But when I have another person with me [co-worker] and I say my thing, the other person can resist this, like 'No, it is done like this'. But then again, I also have the vision for how to do it - we could finish it also in my way - but if this person is more experienced, then he/she is always giving orders.(student_construction)

In a few workplaces in the social and health care field, an emerging tradition of training and co-workers who had recently completed the same qualification were an additional resource for guidance, as they were able to provide feedback on wider studies. The following extract depicts a case, where an apprentice had started training by specialising in substance abuse welfare work, but the trainer aimed to support the entire learning process leading to the apprentice becoming a practical nurse with a wider range of skills:

[Trainer's name] has said to me many times that she wants me to become a professional and knowledgeable practical nurse, so we have to focus on those areas that are not present here, for example, wound care and such, as we do not have a readiness for that here. Then, we discussed the [alternative] training location and what it could be. (apprentice_social)

However, in a few cases, participants of this study expressed that knowledge about the qualification in the workplace was insufficient or outdated. A few learners emphasised 
in their interviews that the teacher should cooperate with the workplace and provide more information on qualifications, requirements and assessment and, eventually, intervene if the learner was facing problems at work. In particular, in the business and administration field, students also highlighted teachers' role in the assessment of their competence. In relation to teaching at school, the individuals' few opinions about the importance of peer groups were varied; for some, peer groups provided new knowledge and support, but, for others, they did not promote learning.

\section{Theme 4: Individuals Alter Boundaries to Participation}

Eventually, the participants' backgrounds, experiences and own activities shaped and altered opportunities to participate in activities in the VET pathways right from the beginning. Some of them were actively involved in the planning of workplace learning and encouraged to do this, whereas some adopted a passive role. The social and health care field, in particular, seemed to support planning, but acknowledging learning opportunities was largely up to the learners. In all sectors, the VET students and apprentices underlined their ability to ask questions and request guidance if needed.

However, based on learners' experiences, especially students and apprentices in the construction sector highlighted the importance of their own backgrounds and agentic actions in enriching learning opportunities. Two students in the construction sector, specialising in infrastructure construction, described how they had grown up with the industry and machines, and in practice, they were autonomous workers despite their student status. In other cases, learners in the construction sector emphasised being flexible and self-directed because work was based on tasks, plans and timetables that were prone to change:

You have to be self-directed and prepare things. You cannot just concentrate on that, that the supervisor gives you one task and then you finish it. You have to think about the whole worksite. (apprentice_construction)

A few of the interviewees felt that in case they lacked a personal vision about how to execute tasks, they were assigned assistive work. From this position, it seemed more difficult to demonstrate the skills and competence needed to receive a more independent position or participate in more motivating and challenging tasks. In one case, agentic actions to receive a more independent role turned out to be disobeying guidance given at work:

Of course, they always say how it [the task] should be done, but if you know better, of course, you do it in your way. I have also advised my teacher many times here at school. (student_construction)

In other cases, agentic actions were related to choosing learning opportunities. In one case, a minor was encouraged to participate in construction tasks, which were restricted due to safety reasons. Eventually, the student decided to defend his rights and refused to do these tasks. Three students in the construction field also intentionally missed attendance at vocational school in preference for work. Otherwise, individual 
accounts from the participants showed that learners actively attempted to promote their participation by actively seeking to enter meetings, participate in job rotation or working extra hours in another workplaces to promote learning opportunities. In summary, it is suggested that all the four themes (see also Appendix Table 2) and findings of this study are interconnected, and that participation in workplace learning is a result of a complex set of factors.

\section{Discussion and Conclusion}

This study examined two vocational learning pathways, school-based VET and apprenticeships. According to the findings of this study, there seemed to be a tendency that apprenticeship training as an employment relationship was based on the productive work and goals of the workplaces, and, thus, apprentices specialised in a particular situated practice. In contrast, workplace learning as part of school-based VET allowed and promoted learner roles, including the setting of educational goals, negotiating tasks and employing a wider range of support from teachers and trainers. This finding suggests that students in school-based VET were legitimate peripheral participants (Lave and Wenger 1991), whereas apprentices' experienced curriculum (Billett 2006) suggested that they were full participants from the beginning. These results reflect those of Reegård (2015) and Goller et al. (2018) who found that novices were given a lot of responsibility and that productive work was expected from them early on. In the case of apprenticeship training, vocational education did not prepare for workplace learning; instead, apprentices were provided contact days during studies. However, it was largely the task of apprentices to combine these learning opportunities, and these sites were often considered to be poorly aligned (cf. Bouw et al. 2019). In contrast, students in school-based VET were timely prepared for workplace learning, and they were able to gradually progress into more demanding tasks. Overall, these suggested differences between vocational pathways match those observed by Grytnes et al. (2018), who concluded that connectivity and learners' employment status (apprentice or student) were related to learning and support.

School-based VET students' and apprentices' experiences suggest that there are some field-related differences regarding workplace learning. In the construction sector, future builders had similar, often assistive, tasks in both learning pathways. Overall, learners emphasised their proactive role and actions in engaging in learning opportunities, but these were considered especially important in the construction sector. This finding is supported by the survey of Virtanen et al. (2014a), as they identified less connectivity and highlighted the importance of student-related individual factors in relation to workplace learning in the technology field compared to in the social and health care field. The findings from this study suggest that in the social and health care field, workplace learning is more structured by the school. In addition, the work allows easier progression into more demanding tasks; workplaces have traditions of training and more collective guidance practices, whereas in the construction sector tasks may be limited due to production and safety reasons, and learners may be put in a marginalised role in the hierarchy, only being allowed to carry out observation and assistive tasks. This finding is contrary to the study by Fjellström and Kristmansson (2016), as they concluded that apprentices performed highly complex tasks with high accountability. 
However, they highlighted that educational goals were often overridden by the workplace goals, which also seemed to be the case in the Finnish context especially in the construction field and more generally in apprenticeship training.

Despite the learning opportunities and vocational pathways provided, individuals eventually decide how they can or choose to engage in these learning opportunities (e.g. Billett 2004; Goller and Harteis 2017). Often apprentices were autonomous workers, whereas a student role enabled the focus to be on learning. However, some of the students in school-based VET were able to act as autonomous workers, whereas some of the apprentices that were officially employed and paid were assigned to assistive or specialised tasks requiring narrow skills. Some of the interviewees felt that progression into more challenging tasks was dependent on the division of the work and other workers, which did not allow for the demonstration of competence, whereas some emphasised their skills, determination and motivation. Participants engaged in agentic actions in order to alter their learning opportunities, for instance, by asking for help and feedback (cf. Goller et al. 2018), preferring to do things their own way and working alone or even by neglecting vocational education. Overall, the themes recognised in this study have similarities with Thornton Moore's (2004) study highlighting environment, organisation and individual features. However, in this study, work practices and social practices related to student's experiences in various organisations and communities were described separately.

This qualitative study has certain limitations. First, this study is located in the Finnish context, and, therefore, the applicability of the findings might be limited. In this context, for example, apprenticeship training refers to a vocational pathway that is based on an employment contract, and it is mainly utilised by adults. Thus, it should be noted that apprentices in this study were older than in many other countries. Second, the sample drawn from two vocational pathways and three fields was relatively small. Therefore, the study was only able to suggest certain tendencies in students' experiences.

This study argues that based on learners' experiences, learning pathways cannot be considered as parallel or interchangeable. In the Finnish context, this implies that the flexible combination of these pathways, as promoted in the reform of VET, is not without challenges because the learner is put in different positions and meets various expectations in each of these pathways. Future studies should investigate how more individualised learning pathways are realised after the reform. This study suggests that there is a need to acknowledge these kinds of inner diversities in a VET system (see also Jørgensen 2018). This may also be relevant for other VET systems, although student-related individual differences might play a considerable role (see also Poortman 2007; Virtanen et al. 2014a). These context- and individual-related issues need to be further studied.

Acknowledgments This research is part of research projects Next Move 2 (Apprenticeship Fund, City of Tampere) and Skills, Education and the Future of Work (Strategic Research Council, Academy of Finland).

\section{Compliance with Ethical Standards}

Conflict of Interest The authors declare no conflict of interest. 


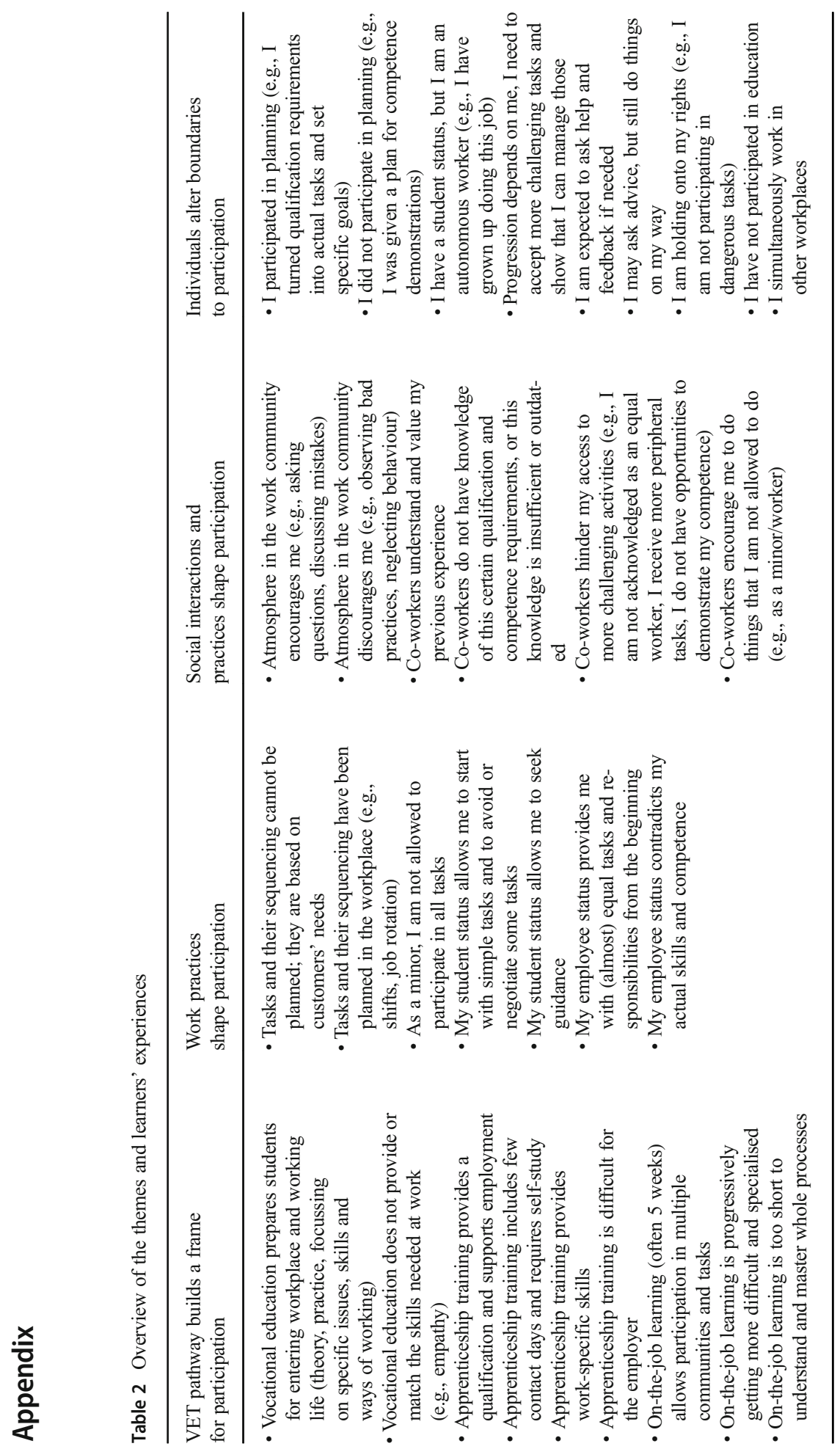




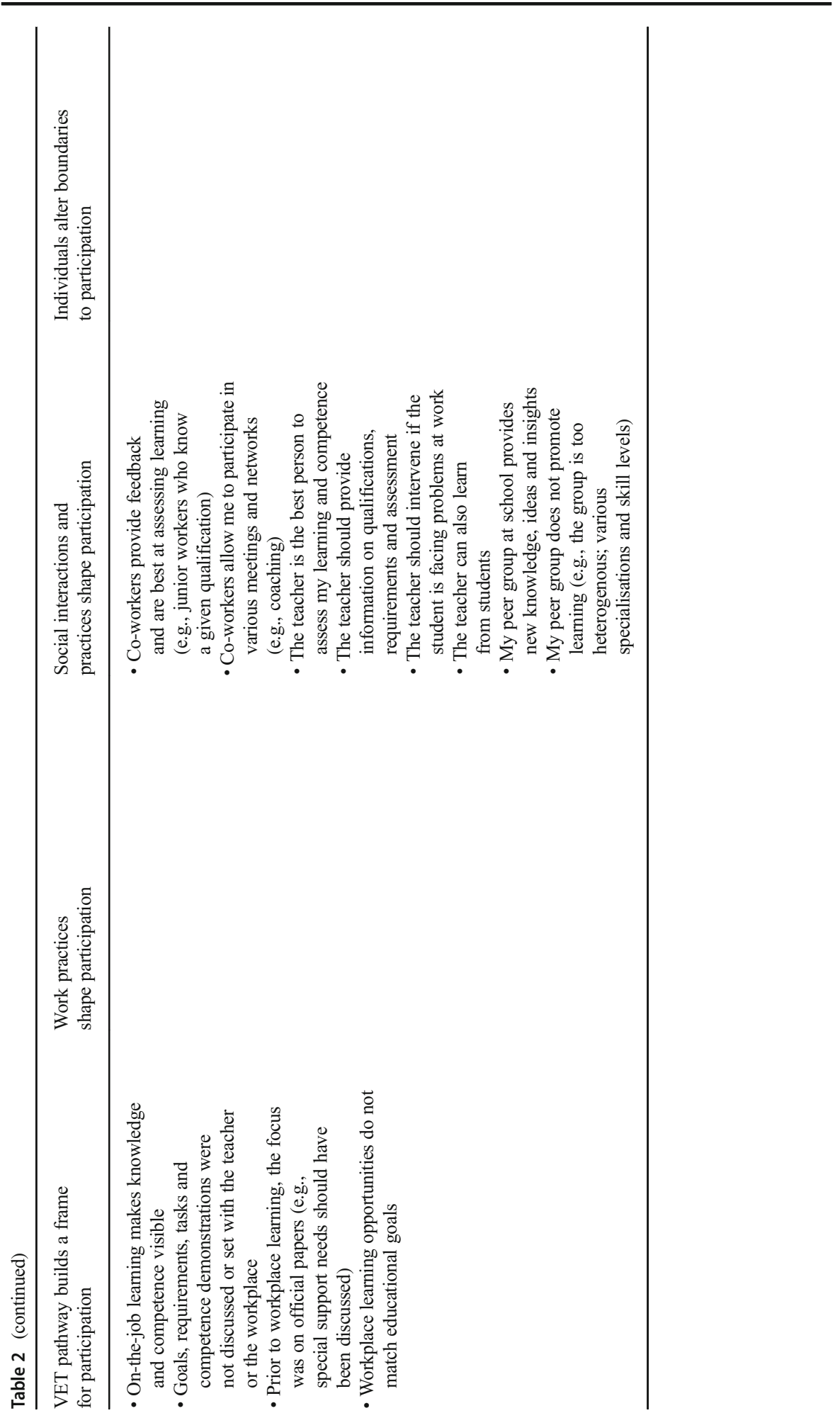


Open Access This article is distributed under the terms of the Creative Commons Attribution 4.0 International License (http://creativecommons.org/licenses/by/4.0/), which permits unrestricted use, distribution, and reproduction in any medium, provided you give appropriate credit to the original author(s) and the source, provide a link to the Creative Commons license, and indicate if changes were made.

\section{References}

Aarkrog, V. (2005). Learning in the workplace and the significance of school-based education: a study of learning in a Danish vocational education and training programme. International Journal of Lifelong Education, 24(2), 137-147.

Akkerman, S. F., \& Bakker, A. (2012). Crossing boundaries between school and work during apprenticeships. Vocations and Learning, 5(2), 153-173.

Billett, S. (2002). Toward a workplace pedagogy: guidance, participation, and engagement. Adult Education Quarterly, 53(1), 27-43.

Billett, S. (2004). Co-participation at work: learning through work and throughout working lives. Studies in Education of Adults, 36(2), 190-205.

Billett, S. (2006). Constituting the workplace curriculum. Journal of Curriculum Studies, 38(1), 31-48.

Billett, S. (2011). Workplace curriculum: Practice and propositions. In F. Dochy, D. Gijbels, M. Segers, \& P. Van den Bossche (Eds.), Theories of learning for the workplace: Building blocks for training and professional development programmes (pp. 17-36). London: Routledge.

Bound, H., \& Lin, M. (2013). Developing competence at work. Vocations and Learning, 6(3), 403-420.

Bouw, E., Zitter, I., \& de Bruijn, E. (2019). Characteristics of learning environments at the boundary between school and work: A literature review. Educational Research Review, 26(1), 1-15.

Braun, V., \& Clarke, V. (2006). Using thematic analysis in psychology. Qualitative Research in Psychology, $3(2), 77-101$.

Clarke, V., \& Braun, V. (2017). Thematic analysis. The Journal of Positive Psychology, 12(3), $297-298$.

Education Statistics Finland. (2018). Students and qualifications. https://vipunen.fi/engb/vocational/Pages/Opiskelijat-ja-tutkinnot.aspx. Accessed 14 Jan 2019.

Eteläpelto, A. (2017). Emerging conceptualisations on professional agency and learning. In M. Goller \& S. Paloniemi (Eds.), Agency at work. Agentic perspective on professional learning and development (pp. 183-201). Cham: Springer.

European Council (2018). Recommendation on a European framework for quality and effective apprenticeships. 2017/0244 (NLE). http://data.consilium.europa.eu/doc/document/ST-6779-2018-INIT/en/pdf. Accessed 13 Feb 2019.

Evans, K., Guile, D., \& Harris, J. (2013). Rethinking work-based learning: For education professionals and professionals who educate. In M. Malloch, L. Cairns, K. Evans, \& B. O’Connor (Eds.), The SAGE handbook of workplace learning (pp. 149-161). Thousand Oaks, CA: Sage.

Finnish National Agency for Education. (2018). Finnish VET in a nutshell. https:/www.oph. fi/download/165770_finnish_vet_in_a_nutshell.pdf . Accessed 14 Jan 2019.

Fjellström, M., \& Kristmansson, P. (2016). Learning as an apprentice in Sweden: A comparative study on affordances for vocational learning in school and work life apprentice education. Education + Training, 58(6), 629-642.

Gherardi, S., Nicolini, D., \& Odella, F. (1998). Toward a social understanding of how people learn in organizations. Management Learning, 29(3), 273-297.

Goller, M., \& Harteis, C. (2017). Human agency at work: Towards a clarification and operationalisation of the concept. In M. Goller \& S. Paloniemi (Eds.), Agency at work. Agentic perspective on professional learning and development (pp. 85-103). Cham: Springer.

Goller, M., Steffen, B., \& Harteis, C. (2018). Becoming a nurse aide: An investigation of an existing workplace curriculum in a nursing home. Vocations and Learning, 12(1), 67-85.

Grytnes, R., Grill, M., Pousette, A., Törner, M., \& Nielsen, K. J. (2018). Apprentice or student? The structures of construction industry vocational education and training in Denmark and Sweden and their possible consequences for safety learning. Vocations and Learning, 11(1), 65-87.

Guile, D., \& Griffiths, T. (2001). Learning through work experience. Journal of Education and Work, 14(1), $113-131$. 
Jørgensen, C. H. (2018). Vocational education and training in the Nordic countries: Different systems and common challenges. In C. H. Jørgensen, O. J. Olsen, \& D. Persson Thunqvist (Eds.), Vocational education in the Nordic countries: Learning from diversity (pp. 1-28). London \& New York: Routledge.

Lave, J., \& Wenger, E. (1991). Situated learning: Legitimate peripheral participation. Cambridge: Cambridge University Press.

Mazenod, A. (2016). Education or training? A comparative perspective on apprenticeships in England. Journal of Vocational Education \& Training, 68(1), 102-117.

Mikkonen, S., Pylväs, L., Rintala, H., Nokelainen, P., \& Postareff, L. (2017). Guiding workplace learning in vocational education and training: A literature review. Empirical Research in Vocational Education and Training, 9(9), 1-22.

Onstenk, J., \& Blokhuis, F. (2007). Apprenticeship in the Netherlands: Connecting school- and work-based learning. Education + Training, 49(6), 489-499.

Poortman, C. L. (2007). Workplace learning processes in senior secondary vocational education. Enschede: University of Twente.

Reegård, K. (2015). Sales assistant in the making: Learning through responsibility. Vocations and Learning, $8(2), 117-133$.

Ryan, P., Backes-Gellner, U., Teuber, S., \& Wagner, K. (2013). Apprentice pay in Britain, Germany and Switzerland: Institutions, market forces and market power. European Journal of Industrial Relations, 19(3), 201-220.

Sappa, V., \& Aprea, C. (2014). Conceptions of connectivity: How Swiss teachers, trainers and apprentices perceive vocational learning and teaching across different learning sites. Vocations and Learning, 7(3), 263-287.

Schaap, H., Baartman, L. K. J., \& de Bruijn, E. (2012). Students' learning processes during school-based learning and workplace learning in vocational education: A review. Vocations and Learning, 5(2), 99117.

Stenström, M.-L., \& Virolainen, M. (2018). The development of Finnish vocational education and training from 1850 to 1945 . In S. Michelsen \& M.-L. Stenström (Eds.), Vocational education in the Nordic countries: The historical evolution (pp. 24-45). Oxon: Routledge.

Swager, R., Klarus, R., van Merriënboer, J. J. G., \& Nieuwenhuis, L. F. M. (2015). Constituent aspects of workplace guidance in secondary VET. European Journal of Training and Development, 39(5), 358-372.

Terry, G., Hayfield, N., Clarke, V., \& Braun, V. (2017). Thematic analysis. In C. Willig \& W. S. Rogers (Eds.), The Sage handbook of qualitative research in psychology (2nd ed., pp. 17-37). London: Sage.

Thornton Moore, D. (2004). Curriculum at work: an educational perspective on the workplace as a learning environment. Journal of Workplace Learning, 16(6), 325-340.

Tynjälä, P. (2013). Toward a 3-P model of workplace learning: a literature review. Vocations and Learning, $6(1), 11-36$.

Virolainen, M., \& Persson Thunqvist, D. (2017). Varieties of universalism: Post-1990s developments in the initial school-based model of VET in Finland and Sweden and implications for transitions to the world of work and higher education. Journal of Vocational Education and Training, 69(1), 47-63.

Virtanen, A., Tynjälä, P., \& Stenström, M.-L. (2008). Field-specific practices as a source for students' vocational identity formation. In S. Billett, C. Harteis, \& A. Eteläpelto (Eds.), Emerging perspectives of workplace learning (pp. 19-34). Rotterdam: Sense.

Virtanen, A., Tynjälä, P., \& Collin, K. (2009). Characteristics of workplace learning among vocational students. Vocations and Learning, 2(3), 153-175.

Virtanen, A., Tynjälä, P., \& Eteläpelto, A. (2014a). Factors promoting vocational students learning at work: Study on student experiences. Journal of Education and Work, 27(1), 43-70.

Virtanen, A., Tynjälä, P., \& Eteläpelto, A. (2014b). Opiskelijoiden työssäoppimista selittävät tekijät kaupan ja hallinnon alalla sekä matkailu-, ravitsemis- ja talousalalla. Ammattikasvatuksen aikakauskirja, 16(4), 44-59.

Publisher's Note Springer Nature remains neutral with regard to jurisdictional claims in published maps and institutional affiliations.

Heta Rintala is a PhD student at Tampere University, Finland. Her research focuses on vocational education and training and workplace learning.

Dr. Petri Nokelainen is a Professor of Engineering Pedagogy at Tampere University, Finland. His research focuses on issues related to development of expertise and professional growth in the contexts of secondary and tertiary education. 